\title{
Strategic Analysis (BAZNAS) SUMUT on Impossible Assistance and Development in Productive Zakat Management
}

\author{
Asmuni $^{1}$, Andri Soemitra ${ }^{2}$, Ermi Suhartyni ${ }^{3}$ \\ ${ }_{1,2,3}$ Universitas Islam Negeri Sumatera Utara, Indonesia \\ spscounter@gmail.com
}

\begin{abstract}
This research is motivated by the problem of Mustahik's success rate in managing productive zakat at the National Amil Zakat Board (BAZNAS) North Sumatradid not show the results as expected. This research aims: 1) To know the Mustahik Mentoring and Mentoring Program in management productive zakat on the National Amil Zakat Board (BAZNAS) North Sumatra. 2) To analyze the strategy of the National Zakat Agency (BAZNAS) North Sumatra on Assistance and Guidance of Mustahik inmanagement productive zakat. 3) To analyze the strategy of the National Zakat Agency (BAZNAS) North Sumatra on Assistance and Guidance of Mustahik inmanagement productive zakat in accordance with the concept of sharia. The research method used is qualitative research methods, data collection through observation, interviews and documentation and questionnaires. The data analysis used is interactive analysis (Miles and Huberman) to analyze the potential of the National Zakat Agency. (BAZNAS) North Sumatra, Mentoring and Guidance program and Mustahik's perception. SWOT analysis as the basis for formulating the strategy of the National Zakat Agency (BAZNAS) North Sumatra in the productive Mustahik Assistance and Development program. The results show that Mustahik in managing productive zakat has not received assistance and guidance from the National Zakat Agency (Amil Zakat).BAZNAS) North Sumatra.
\end{abstract}

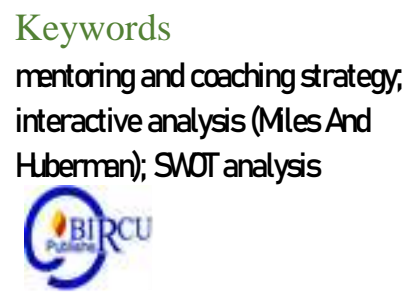

Keywords

mentoring and coaching strategy, interactive analysis (Mles And Huberman); ShOT analysis

\section{Introduction}

In terms of quantity, the Muslim community in Indonesia is the largest Muslim community when compared to other religious communities, even Indonesia is called a country with a large Islamic community in the world. Currently, the Muslim community in Indonesia is estimated at 207 million or around $87.2 \%$ based on data from the Ministry of Information and Public Communication. ${ }^{1}$

Indonesia is not an Islamic country, but at least $87 \%$ of Indonesia's population adheres to the teachings of Islam, of course, more or less it will have an impact on people's lives in Indonesia, both politically, economically, socially and others. Furthermore, if the economic condition of the Indonesian Muslim community improves, it will be a representation of the improving economic condition of the Indonesian nation. ${ }^{2}$

From the interview, the authors get an idea that the zakat funds distributed to mustahik are still far from sufficient, just to cover up the difficulties experienced by Mustahik. If this is followed up with comprehensive and comprehensive mentoring and guidance to supervision, it is very likely

\footnotetext{
${ }^{1}$ https: // www. Indonesia. go.id/ religion. Data accessed on 23 July 2019. At 9.34. WIB.

${ }^{2}$ Megawati, Devi, Evaluation of the Mustahiq Empowerment Program "Etawa Goat at the City Baz Week, Pekbis Journal, 6.3 (2014), 79-169.
} 
that the zakat fund will be able to lead these traders to a better and independent life, even a better possibility, namely the realization of the transformation from Mustahik to muzzaki.

SupposedlyBAZNAS North Sumatrais an institution that manages official zakat from a country whose working area covers the entire region of North Sumatra, not only distributing zakat in consumptive form but in this case also distributing productive zakat. The North Sumatra Regional Amil Zakat Board should also carry out assistance and guidance to Mustahik as has been implemented by other Amil Zakat Institutions.

The author believes that through mentoring and coaching for Mustahik carried out by professional stakeholders will have a positive influence on changes in Mustahik's life welfare level will be realized, as was also carried out by other Amil Zakat. This is what supports the author to conduct research specifically onBAZNASNorth Sumatra. This research was conducted forNorth Sumatra BAZNAS Strategy Analysis on Assistance and Guidance of Mustahik In fostering mustahik in the management of Productive Zakat productive zakat.

\subsection{Formulation of the Problem}

Based on the background of the problem, so it is proposed as a problem formulation. in a study with the following research questions:

1. How is the Mustahik Assistance and Development Program in the management of productive zakat in North Sumatra BAZNAS.

2. How is the North Sumatra BAZNAS Mustahik Assistance and Development strategy in the management of productive zakat.

3. How is the North Sumatra BAZNAS strategy on Mustahik Assistance and Development in the management of productive zakat in accordance with the concept of sharia.

\section{Review of Literatures}

\subsection{Strategy}

Strategy is a means of achieving goals. The strategic design is continually developing and each individual has an idea with the design of various strategies. In Greek, strategy "strategia" means "the art of the general" meaning the art of a common man used in times of war. For understanding in general, strategy namely a way to achieve a goal or gain victory. Strategy is both a science is art to develop strength) to achieve the goals you have planned on moments before. ${ }^{3}$

Based on some of the explanations above, it can be concluded that an institution or organization with good management should have a strategy, even though it is not shown in real terms. Ensure general directions that an institution or company is trying to reach in reaching out a predefined plan previous. This strategy is an essential plan and a grand plan.

\subsection{Accompaniment}

The word accompaniment consists of 2 syllables "damping" which means familiar (brothers). close, a meeting that ends with "an" so "side by side" implies a full life of helping one another. Furthermore, given the prefix "pen" so that "companion" means accompanying also accompanying, there is always a state of grief or joy. ${ }^{4}$ Mentoring is cooperation between the

\footnotetext{
${ }^{3}$ Rahmat Hidayat and Ricky Rahmat, "Swot Analysis as a Basis for Marketing Strategy Decisions in Credit Server Companies in Batam City (Case Study at Cv. Star Pratama)," Journal of Applied Business Administration Vol 2, No. 1, March 2018, 2.1 (2018), 94-108 $<$ https://jurnal.polibatam.ac.id/index.php/JABA/article/download/745/551>.

${ }^{4}$ Mulyati Purwasasmita, "Strategy of Assistance for the Improvement of Community Beujar Independence," UPI Educational Administration Journal, 12.2 (2010).
} 
counterparty and the client which is based on mutual respect and trust. Assistance is a teaching medium that is seen as very effective and effective in helping someone to facilitate or provide facilities for determining and solving problems and encouraging a sense of initiative in making decisions so that independence can be realized, in other words helping someone realize their dreams. the city. In this case, it is necessary to involve practitioners, entrepreneurs, and professional stakeholders in the mentoring program so that the aims and objectives of mentoring produce maximum results. ${ }^{5}$ All assistance activities must be controlled in such a way by the parties involved. With this mentoring pattern, there will be a complete database that records Mustahik's business developments. Companies easily learn about weaknesses and business developments and can provide advice according to their respective needs according to the cases they face in the field.

\subsection{Development}

Coaching is an educational process by explaining all things that have been mastered and deepening, reviewing new things that were not previously owned, by providing assistance to those who are living it, to improve and improve existing skills and understanding and be able to understand and have the intelligence that new to work and achieve life goals, which are lived better. $^{6}$

According to R. Wayne Mondy, coaching is the provision of lessons where people acquire competencies, expertise, talents, skills needed in their current activities. ${ }^{7}$

The conclusion that can be drawn from the previous description is that coaching is a learning process as an effort to improve and develop skills and understanding and attitudes of a person or group of people, with the hope that changes will occur in a direction that is more optimal than the conditions that occurred at the time before, which begins with activities plan, preparation, cost, coordination, process up to the supervision of the task in achieving the expected goals in order to get the maximum possible result.

\subsection{Productive Zakat}

The origin of the productive vocabulary in English is "productive" which means profitable, useful, useful, and can generate income, have a profit. "Productive zakat according to Didin Hafidhuddin, "zakat distributed to the poor in the form of capital or otherwise can be used for business capital, and in the end it is able to increase Mustahik's standard of living, and through this zakat a Mustahik is expected to become Muzakki if he can use it. These funds are well in its economic activity. ${ }^{9}$

Through the effectiveness of zakat utilization productively, it means that zakat does not only help one side, namely changing the life of the Mustahik people, but at the macro level it can improve the economy of the people and can even minimize the unemployment rate that occurs in Indonesia. This is of course through creative productive zakat empowerment, because the creation of new jobs that are able to absorb labor

\footnotetext{
${ }^{5}$ Bambang Adi Suryono, UMKM Facilitator Assistance Patterns in Creating Rebana Center, Journal of Education for All, Vol 2 No. 1 Year 2018, p. 8 - 18

${ }^{5}$ Rakhma., h. 7.

${ }^{6}$ A. Mangunhardjana, Coaching: Meaning and Methods, (Yogjakarta: Kanisius, 1991), p. 12.

${ }^{7}$ Mondy R Wayne Human Resource Management, (Jakarta: Erlangga, 2008), p. 95

${ }^{8}$ Joyce. M. Hawkins, English-Indonesian, Indonesian-English Dual Dictionary, (Oxford-Erlangga. 1996), p. 267

${ }^{9}$ Didin Hafidhuddin, Zakat in the Modern Economy, (Jakarta: Gema Insani Press Cet. II, 2002), p. 45
} 


\subsection{Muzakki And Mustahik}

Muzakki is an important part in the context of the zakat process. Muzakki is a person or group of people who have an obligation to pay zakat. ${ }^{10}$.Mustahik is a society that has the right to obtain zakat, the terms and laws related to zakat are regulated in the Al Quran Surah at-taubah 9 verse 60

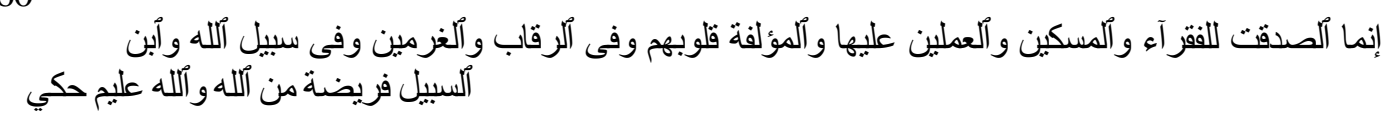

That is, 'actually zakat is only for the needy, poor people and amil zakat softened his heart or not to liberate my slave, to free people who owe for the sake of Allah's path and for people who are on their way as duty from Allah. Allah is All-Knowing the wise (Surah at-taubah 9: 60)

Poor people actually have great potential such as energy, mental intelligence, skills and even various skills to produce works that are appreciated in the midst of society, but they do not have the ability to obtain, own and access these resources, so in the end they will remain in the same zone throughout their life, namely remaining in a state of poverty. Hasbi as shiddiqi, emphasized that being poor is a condition of someone who really needs help and helping hands from others, but that person does not ask anywhere because of their poor condition. ${ }^{11}$

\subsection{Assistance Relationship, Impossible Development with Productive Zakat Management}

Furthermore, Ari Haryanto emphasized that the provision of productive zakat funds is always accompanied by assistance to Mustahik, this is because the provision of Mustahik funds must always be used as expected so that the funds will always develop. ${ }^{12}$

Assistance activities are carried out aimed at supporting the progress of the efforts made by Mustahik as well as for assistants to provide suggestions and alternatives as the right choice to solve problems in the form of obstacles that may be faced by Mustahik, and can support Mustahik's assistance to be more effective.

In essence, the aim of this assistance is to foster enthusiasm for Mustahik in carrying out his business to achieve the goal, namely to gain blessings. So the hope is that Mustahik who is assisted in the mentoring program can become Muzakki. In this case the task of empowering the mentoring and fostering of the poor is the competence possessed by group members and have the skills to manage their business.

\footnotetext{
${ }^{10}$ Law of the Republic of Indonesia Number 38 of 1999 Article 1 concerning Management of Zakat,

${ }^{11}$ Hasbi ash-shiddieqy, Zakat Law, (Semarang: PT Pustaka Rizki Putra, 2002) h. 148.

${ }^{12}$ Ari Haryanto Chandra, The Impact of Productive Infaq Utilization on Increased Income at Mustahiq Ydsf (Al-Falah Social Fund Foundation) in KediriJESTT Vol. 1 No. October 10, 2014, "1.10 (2014), 720-735.
} 


\subsection{Framework}

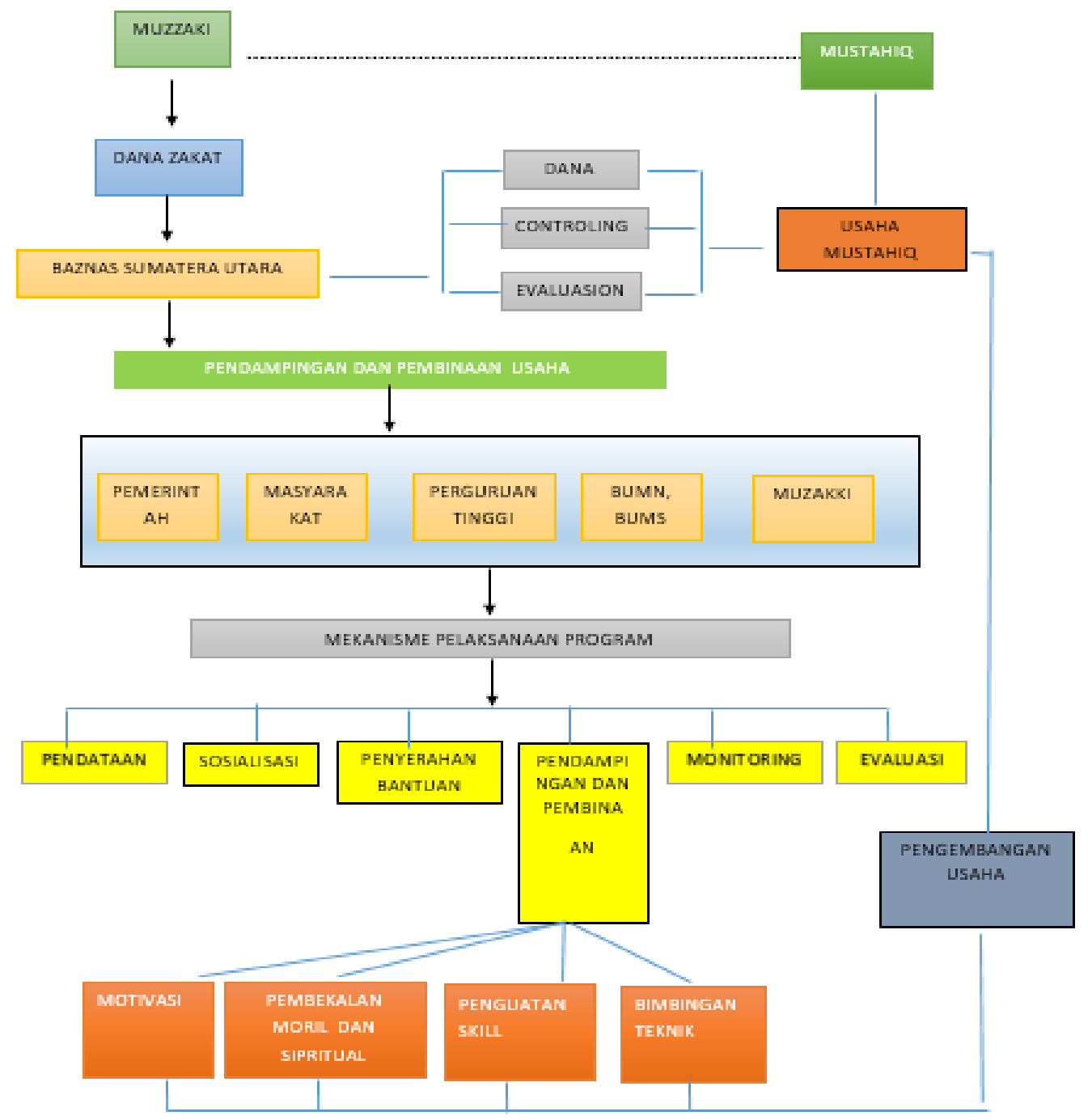

\section{Research Methods}

This research is a qualitative research to find out phenomena related to what is experienced by research subjects such as perceptions, motivations, behaviors, actions and so on through exposure in the form of words and language, in special contexts that are natural and by using various natural methods. ${ }^{13}$ Another consideration is that the implementation of Mustahik's mentoring and guidance program is expected to reveal hidden things from the implementation of the program. Therefore, researchers become more sensitive to descriptive information by maintaining the authenticity of the object under study.

${ }^{13}$ Moleong, LJ, Qualitative Research Methods Revised Edition, (Bandung: Pt. Remaja Rosdakarya, 2011), h. 6. 


\subsection{Research Focus}

The focus of qualitative research is intended to limit qualitative studies, as well as limit researchers in determining relevant and irrelevant data. Based on this concept, the focus in this study is described as follows:

(1) Implementation of the Mustahik business assistance and development program by BAZNAS North Sumatra.

(2) Mustahik's perception of BAZNAS North Sumatra. in assistance and guidance It is impossible to manage productive zakat.

(3) Strengths, weaknesses, opportunities and threats BAZNAS North Sumatra in mentoring and fostering Mustahik in the management of productive zakat.

\subsection{Data Source}

The data collection technique in this study was carried out selectively. Sources of data in the study were obtained from the person or subject being studied as informants, events, and documents. Written data such as official documents, magazines etc. is a source of data that can support the main data in this qualitative research. Therefore, the types of data extracted can be distinguished as follows:

(1) Words and actions The words and actions of the people being interviewed or observed are the main data.

(2) Written data

This written data can be obtained from data sources in the form of scientific books and magazines, archives, personal documents, and official documents.

(3) Photo

(4) Statistics

(4) Furthermore, preliminary information in qualitative research was selected purposively (purposive sampling) based on the subject of the problem, had data and was willing to provide data. Key informants, in this study are members of the boardBAZNAS North Sumatrafrom North Sumatra BAZNAS officials.

\subsection{Research Instruments}

Researcher is the key instrument or main research tool. Researchers conducted unstructured observations or interviews using notebooks.

\subsection{Data Collection}

In this study, researchers used tools in the form of field notes and interview guides. Data collection (Logging the data) is done in several ways, namely interviews (Interview), observation (Observation), and documentation and questionnaires.

\subsection{Data Analysis}

In this study, data analysis was carried out almost simultaneously with the data collection process, namely from the beginning and throughout the research process. In this qualitative research, researchers used data analysis from:

1) Miles and Huberman (1992: 16-19) with the following procedure:

a. Data reduction

b. Presentation of Data

c. Draw Conclusions / Verification follows:

Miles and Huberman's (1992) interactive model data analysis can be described as 


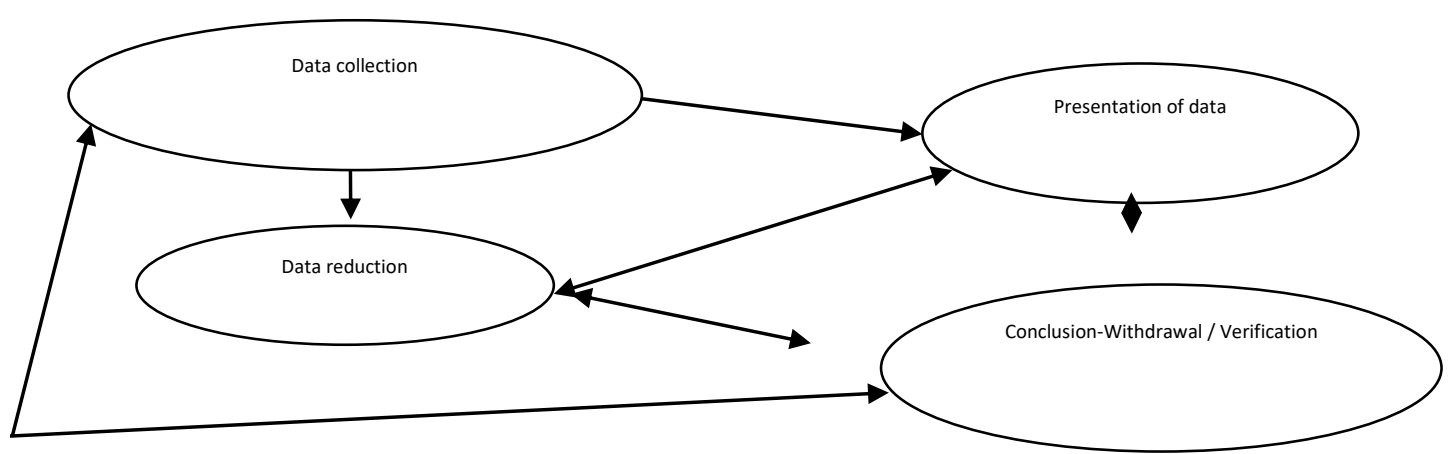

Figure 1. Interactive Model Data Analysis ${ }^{14}$

2) SWOT analysis

Minzberg said that SWOT analysis is a strategic plan that contains facts, evidence, figures and values that are interrelated with one another. ${ }^{15}$ In another definition, SWOT is a useful tool for determining problems related to internal and external factors in a company ${ }^{16}$

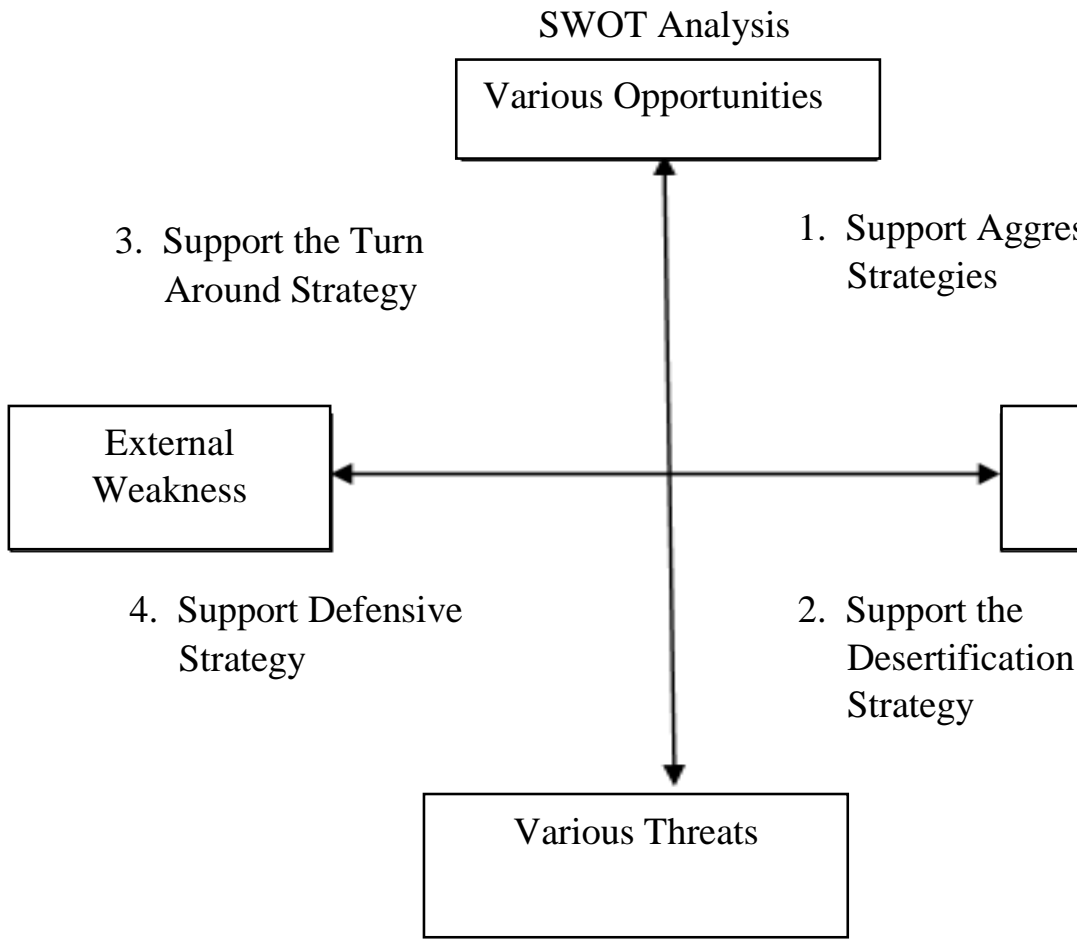

\section{Quadrant 1.}

Is a very favorable situation for the company. The strategy that must be determined in this condition is to support an aggressive growth policy (Growth oriented strategy).

\footnotetext{
${ }^{14}$ Miles and Huberman, Qualitative Data Analysis, (Jakarta: UI-Press, 1992), p. 20

${ }^{15}$ Henry Mintzberg, The Rise And Fall Of Strategic Planning, New York: Free Press, 1994.

${ }^{16}$ Erhad. K. Valentin, Away Whitn SWOT Analysis: Use Defensive Offensive Evalation Instead ", in Journal Of Applied Business Research Spring, 2005, Vol 2i, No. 2. h. 91.
} 


\section{Quadrant 2.}

Despite being faced with various threats, this company still has strength from an internal perspective. Strategy is to use the company's strengths to take advantage of long-term opportunities by means of a diversification strategy (product / market)

\section{Quadrant 3.}

The company is faced with a very large market opportunity, but on the other hand the company is also faced with several existing internal constraints / weaknesses. the strategy is to minimize the internal problems faced so that the company can seize better market opportunities.

\section{Quadrant 4.}

This is a very unfavorable situation for the company.

\subsection{Data Validity}

The emphasis in testing the validity of the data in this study is on the validity and reliability tests. There are four (4) stages of research activities to reach the depth (Depth) of research and to test the validity of data in qualitative research developed by Lincoln and Guba (1985), namely:

(1) Credibility (degree of confidence)

(2) Transferability (Transferability)

(3) Dependability (Helpfulness)

(4) Conformability (certainty)

\section{Discussion}

\subsection{Mustahik Assistance and Development Program in the management of productive zakat on BAZNAS North Sumatra}

Mentoring program and the coaching BAZNAS North Sumatra based on existing data and the results of interviews with BAZNAS North Sumatra, researchers can describe that program Coaching can not be carried out optimally, because of human resources owned is still limited. In 2014 the program accompaniment has been announced but the implementation is still inadequate, guidance and assistance to recipients of productive revolving loans has only been visited. From research conducted to BAZNAS North Sumatra, it can be concluded that the assistance provided by the National Zakat Agency (BAZNAS) North Sumatra has not met the standards in accordance with the existing theory, because in this theory, assistance goes through 7 stages, from preparation to termination, but in this caseBAZNAS North Sumatrahasn't done that. This is an obstacle for Mustahik to develop his business, because almost all Mustahik have minimal skills in managing venture capital.

4.2 Analysis of Mustahik's Assistance and Guidance strategies in the management of productive zakat byBAZNAS North Sumatra

Based on the observations in the field, it can be concluded that BAZNAS North Sumatra has internal strengths and weaknesses, as well as opportunities and threats as described in the following table: 
Table 1. Strengths and weaknesses (Strength and Weakness) BAZNAS North Sumatra

\begin{tabular}{|c|l|}
\hline No. & Internal Strength and Weakness Factors \\
\hline 1 & \begin{tabular}{l} 
Power: \\
a. Has a legal umbrella and is regulated in law \\
b. Education level of North Sumatra BAZNAS management is quite high \\
c. Zakat funds received BAZNAS North Sumatra large enough \\
d. The management of BAZNAS North Sumatra is solid in carrying out its \\
duties. \\
e. North Sumatra BAZNAS management has made use of technological media \\
\hline 2
\end{tabular} \\
$\begin{array}{l}\text { a. Weakness: } \\
\text { b. Lack of professionals involved in Mustahik Development } \\
\text { c. Limited funds to finance coaching intensively. } \\
\text { d. Concurrent positions in the Management of BAZNAS North Sumatra. With } \\
\text { the limited number of human resources and so many programs they have, it } \\
\text { indirectly forces some of the management to hold concurrent positions. } \\
\text { e. North Sumatra BAZNAS is not optimal in utilizing technological media. }\end{array}$ \\
\hline
\end{tabular}

Oportunistis and Threats BAZNAS North Sumatra

\begin{tabular}{|c|c|}
\hline No. & External Opportunity and Threat Factors \\
\hline 1 & $\begin{array}{l}\text { Opportunities: } \\
\text { a. The majority of the population of North Sumatra is Muslim } \\
\text { b. The community has a strong belief in BAZNAS North Sumatra } \\
\text { c. North Sumatra BAZNAS is supported and assisted by the Regional } \\
\text { Government } \\
\text { d. Have the opportunity to cooperate with BUMN and BUMD, State or } \\
\text { Private Universities, MSMEs or other business entities } \\
\text { e. Have the opportunity to run the zakat program that has been set by the } \\
\text { government through the Central BAZNAS. } \\
\text { f. Mustahik's enthusiasm and desire to progress was quite high }\end{array}$ \\
\hline 2 & $\begin{array}{l}\text { Threat: } \\
\text { a. Lack of public knowledge regarding zakat. } \\
\text { b. BAZNAS North Sumatra is not entirely a solution for Muzakki to distribute } \\
\text { his zakat. } \\
\text { c. The government has not been fully involved in the Mustahik Development } \\
\text { d. The involvement of other parties is still lacking } \\
\text { e. From other Amil Zakat Institutions, they provide more attractive programs } \\
\text { so that they become the main attraction for Muzakki and Mustahik. } \\
\text { f. The productive zakat funds that go into Mustahik' s hands will not be able } \\
\text { to change Mustahik' s economic conditions to the maximum. }\end{array}$ \\
\hline
\end{tabular}

4.3 Analysis of Assistance and Development Strategies for Mustahik in Accordance with the Concept of Sharia BAZNAS North Sumatra in Productive Zakat Management

In this study, the researcher developed a strategy based on the results of the SWOT analysis using the IFAS and EFAS matrix approach. 
Table 2. North Sumatra BAZNAS IFAS Matrix

\begin{tabular}{|c|c|c|c|c|c|}
\hline No. & $\begin{array}{c}\text { Internal } \\
\text { Strategy } \\
\text { Factors }\end{array}$ & Weight & Rating & Score & Comment \\
\hline I & \multicolumn{5}{|l|}{ POWER } \\
\hline 1 & Regulation & 0.1165 & 4 & 0.4658 & $\begin{array}{l}\text { Carry out existing } \\
\text { regulations }\end{array}$ \\
\hline 2 & HR & 0.0851 & 2 & 0.1702 & $\begin{array}{l}\text { To do training and } \\
\text { development for employees }\end{array}$ \\
\hline 3 & Fund & 0.1299 & 3 & 0.3897 & $\begin{array}{l}\text { Maximizing the use of } \\
\text { existing funds }\end{array}$ \\
\hline 4 & $\begin{array}{l}\text { Into } \\
\text { management }\end{array}$ & 0.1165 & 3 & 0.3494 & $\begin{array}{l}\text { Improve management } \\
\text { performance }\end{array}$ \\
\hline 5 & $\begin{array}{l}\text { Media } \\
\text { Technology }\end{array}$ & 0.0885 & 2 & 0.1769 & $\begin{array}{l}\text { Maximizing the use of } \\
\text { media technology }\end{array}$ \\
\hline \multicolumn{2}{|c|}{ Total Strength } & 0.5364 & & 1.5521 & \\
\hline II & \multicolumn{5}{|l|}{ WEAKNESS } \\
\hline 1 & Regulation & 0.0795 & 2 & 0.1590 & $\begin{array}{l}\text { Increase understanding of } \\
\text { existing regulations }\end{array}$ \\
\hline 2 & HR & 0.0661 & 2 & 0.1321 & $\begin{array}{l}\text { Improve existing HR } \\
\text { capabilities }\end{array}$ \\
\hline 3 & Fund & 0.1209 & 2 & 0.2419 & $\begin{array}{l}\text { Making funds effective for } \\
\text { productive zakat }\end{array}$ \\
\hline 4 & Management & 0.0672 & 2 & 0.1344 & $\begin{array}{l}\text { Maximizing management } \\
\text { performance }\end{array}$ \\
\hline 5 & $\begin{array}{l}\text { Media } \\
\text { Technology }\end{array}$ & 0.1299 & 3 & 0.3897 & $\begin{array}{l}\text { The use of technology needs } \\
\text { to be improved }\end{array}$ \\
\hline \multicolumn{2}{|c|}{ Total Weakness } & 0.4636 & & 1.0571 & \\
\hline \multicolumn{2}{|c|}{$\begin{array}{l}\text { TOTAL } \\
\text { WHOLE }\end{array}$} & 1.0000 & & 2.6092 & \\
\hline
\end{tabular}

Based on the results of the IFAS matrix in the table above, the conclusion is that the scores are strengths and weaknesses BAZNAS North Sumatra be in the range 2.6092 which means strength BAZNAS North Sumatra to conduct guidance to Mustahik in the management of productive zakat is in a moderate position, so it can be said that BAZNAS North Sumatra must expand by increasing partnership efforts in the hope of increasing the capacity of human resources and Maximizing the use of technology media. When viewed from the score of each indicator, the internal indicator of strength that has the highest score is regulation with a total score of 0.4658 with a rating of 4 , while the lowest is the internal indicator of strength, namely HR with a total score of 0.1702 , with a rating of 2 . 
Table 3. North Sumatra BAZNAS EFAS Matrix

\begin{tabular}{|c|c|c|c|c|c|}
\hline No. & $\begin{array}{c}\text { External } \\
\text { Strategy Factors }\end{array}$ & Weight & Rating & Score & Comment \\
\hline $\mathbf{I}$ & \multicolumn{5}{|c|}{ OPPORTUNITIES } \\
\hline 1 & Demographics & 0.124 & 4 & 0.49751 & $\begin{array}{l}\text { Socialization of zakat to the } \\
\text { community }\end{array}$ \\
\hline 2 & $\begin{array}{l}\text { Community } \\
\text { Trust Level }\end{array}$ & 0.085 & 3 & 0.25500 & Maintain a level of public trust \\
\hline 3 & $\begin{array}{l}\text { Government } \\
\text { policy }\end{array}$ & 0.055 & 2 & 0.10945 & Involve government \\
\hline 4 & Partnership & 0.110 & 3 & 0.33134 & $\begin{array}{l}\text { Intertwine cooperation with } \\
\text { partners who have the same } \\
\text { vision and mission }\end{array}$ \\
\hline 5 & Program & 0.110 & 3 & 0.33134 & $\begin{array}{l}\text { Create interesting and } \\
\text { innovative program }\end{array}$ \\
\hline 6 & Motivation & 0.112 & 3 & 0.33731 & $\begin{array}{l}\text { Created the BAZNAS Reword } \\
\text { program }\end{array}$ \\
\hline \multicolumn{2}{|c|}{ Total Opportunities } & 0.597 & & 1.86195 & \\
\hline II & \multicolumn{5}{|l|}{ THREAT } \\
\hline 1 & Demographics & 0.084 & 2 & 0.16716 & $\begin{array}{l}\text { Hold the government in } \\
\text { assistance }\end{array}$ \\
\hline 2 & $\begin{array}{l}\text { Community } \\
\text { Trust Level }\end{array}$ & 0.054 & 2 & 0.10746 & $\begin{array}{l}\text { Conducting outreach to the } \\
\text { community }\end{array}$ \\
\hline 3 & $\begin{array}{l}\text { Government } \\
\text { policy }\end{array}$ & 0.050 & 2 & 0.0995 & $\begin{array}{l}\text { Maximizing Government } \\
\text { function in relation to } \\
\text { empowerment }\end{array}$ \\
\hline 4 & Partnership & 0.114 & 2 & 0.22886 & Engaging various stakeholders \\
\hline 5 & Program & 0.050 & 2 & 0.0995 & $\begin{array}{l}\text { Create interesting and } \\
\text { innovative program }\end{array}$ \\
\hline 6 & Motivation & 0.052 & 2 & 0.10348 & $\begin{array}{l}\text { Create BAZNAS Reword } \\
\text { Program (PRB) }\end{array}$ \\
\hline \multicolumn{2}{|c|}{ Total Threat } & 0.403 & & 0.80596 & \\
\hline \multicolumn{2}{|c|}{ TOTAL } & 1,000 & & 2.66791 & \\
\hline
\end{tabular}

Source: data processed by researchers 2020

Based on the results of the EFAS matrix in the table above, it can be concluded that the total score of Opportunities and Threats North Sumatra BAZNAS is in the range2.66791 which means strength BAZNAS North Sumatra is in a moderate position, so it can be said that North Sumatra BAZNAS must make improvements by increasing partnerships in the hope of increasing the ability of human resources andmaximize the use of media technology. When viewed from the score of each indicator, the external indicator on opportunities that has the highest score is demography with a total score of 0.49751 with a rating of 4 , this is because the majority of North Sumatra's population is Muslim, 
while the lowest is from the external indicator of opportunity, namely Policy. The government with a total score of 0.10945 , with a rating of 2 . This is because the government's involvement has not been maximalBAZNAS North Sumatra

Based on the IFAS and EFAS matrices above, information on the general conditions of BAZNAS North Sumatra is as follows:

Total Strength score : 1,552

Total Weakness score : 1,057

Total Chance score $\quad: 1,861$

Total Threat score : 0.805

Based on the total score, the position determination of BAZNAS North Sumatra can be described by the following SWOT matrix:

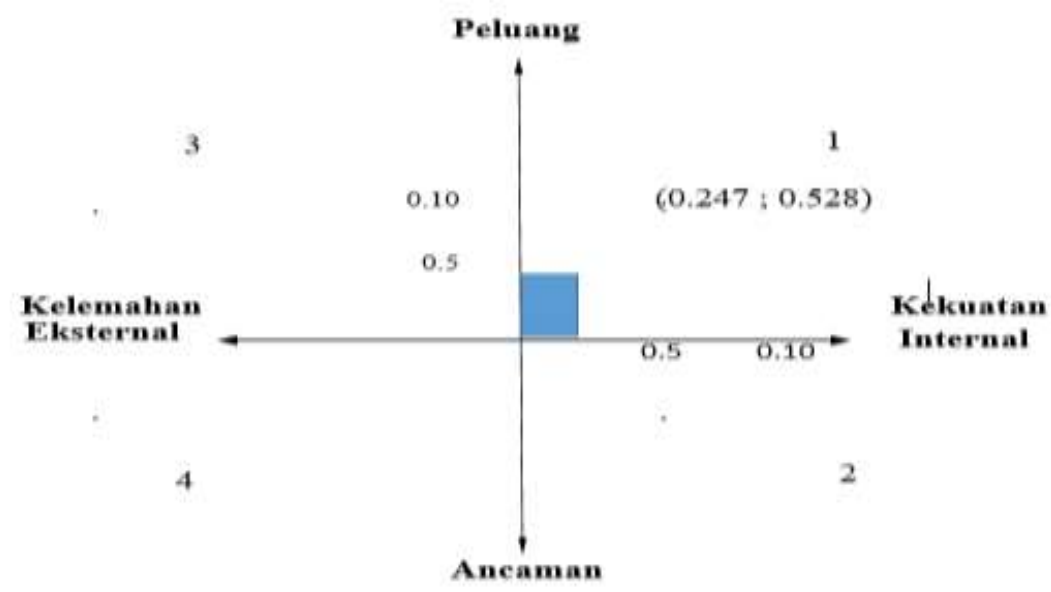

Figure 1. Position of North Sumatra BAZNAS

Source: data processed by researchers 2020

The coordinates of the image are:

Internal Analysis Coordinate: (total strength score - total weakness score) / 2 $=(1,552-1,057) / 2=0.247$

External analysis coordinate: (total chance score - total threat score) / 2

$$
=(1,861-0.805) / 2=0.528
$$

Total Strength score $: 1,552$

Total Weakness score : 1,057

Total Chance score $: 1,861$

Total Threat score : 0.805

The results of the calculations for each quadrant are described as follows:

Table 4. Strategic Priorities for the National Zakat Agency BAZNAS North Sumatra

\begin{tabular}{|l|l|l|l|l|}
\hline Quadrant & Matric position & $\begin{array}{l}\text { Matric } \\
\text { area }\end{array}$ & rank & Strategy priorities \\
\hline I & $(1,552 ; 1,861)$ & 2.888272 & 1 & Growth \\
\hline II & $(1,057 ; 1,861)$ & 1.967077 & 2 & Stability \\
\hline III & $(1,057 ; 0.805)$ & 0.850885 & 4 & Shrinkage \\
\hline IV & $(1,552 ; 0.805)$ & 1.249360 & 3 & Combination \\
\hline
\end{tabular}

Source: data processed by researchers 2020 
From the graph above it can be concluded that BAZNAS North Sumatrahas better strength, so high strength and high opportunities. This position shows thatBAZNAS North Sumatrabe in a position of strength. Recommended to BAZNAS North Sumatra to carry out a progressive strategy by utilizing internal strengths to take advantage of external opportunities by expanding, accelerating growth and achieving maximum progress.

The following describes the SWOT matrix of the National Zakat Agency (BAZNAS) North Sumatra in Mustahik Development in the management of productive zakat. The SWOT matrix analysis process can be seen in the following table:

Table 5. The SWOT Matrix Analysis Process

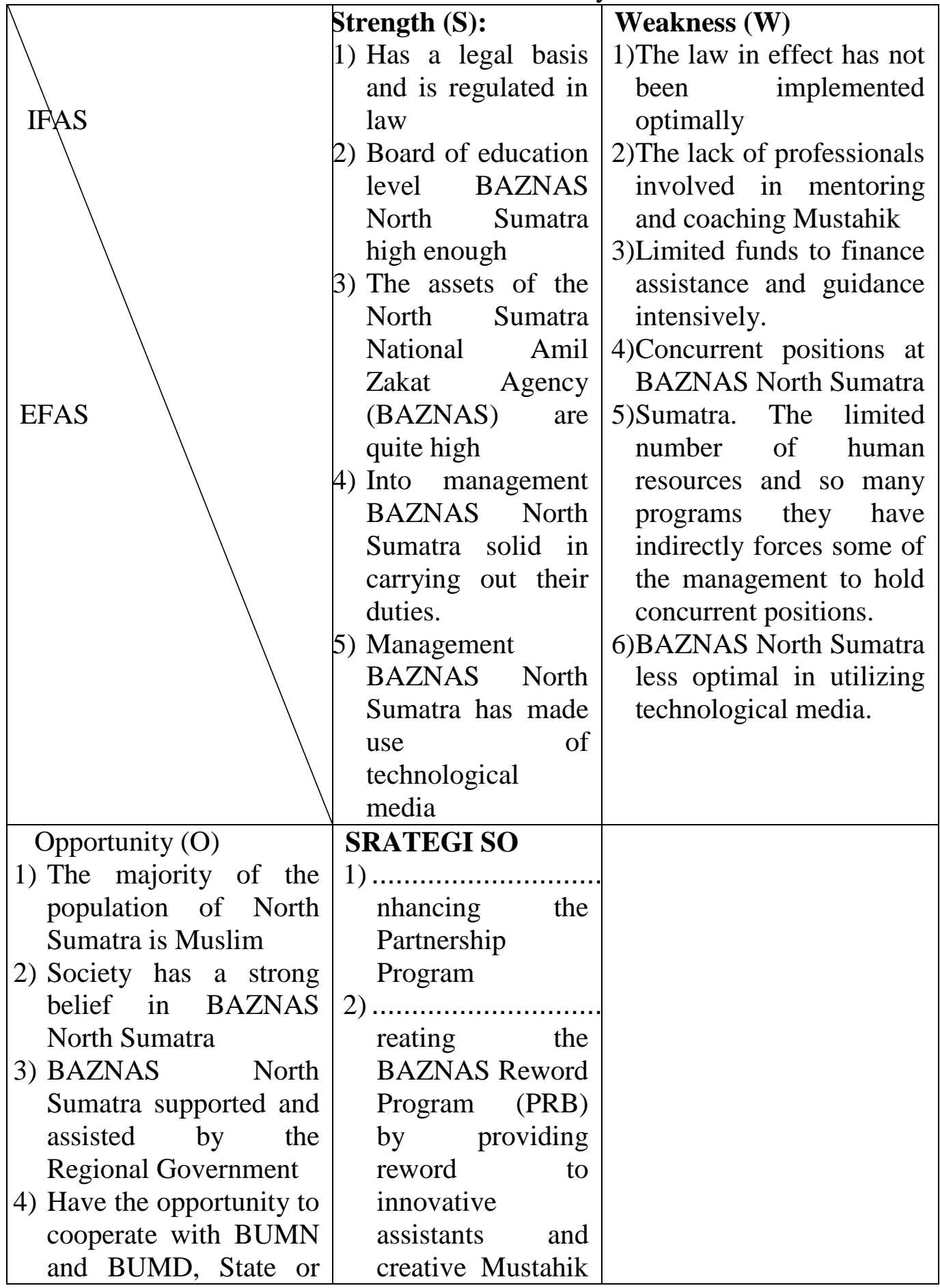




\begin{tabular}{|c|c|c|}
\hline $\begin{array}{l}\text { Private Universities, } \\
\text { MSMEs or other } \\
\text { business entities } \\
\text { 5) Have the opportunity to } \\
\text { run the zakat program } \\
\text { that has been set by the } \\
\text { government through } \\
\text { the Central BAZNAS. } \\
\text { 6) Mustahik' s enthusiasm } \\
\text { and desire to progress } \\
\text { was quite high }\end{array}$ & $\begin{array}{l}\text { in developing } \\
\text { their business. } \\
\text { 3) .......................... } \\
\text { reating a concept } \\
\text { of mentoring and } \\
\text { coaching in } \\
\text { accordance with } \\
\text { the concept of } \\
\text { Islamic sharia } \\
\text { 4) .......................... } \\
\text { reating attractive } \\
\text { and innovative } \\
\text { programs }\end{array}$ & \\
\hline $\begin{array}{l}\text { Threat: (T) } \\
\text { 1) Lack of public } \\
\text { knowledge regarding } \\
\text { zakat. } \\
\text { 2) BAZNAS North } \\
\text { Sumatra not entirely a } \\
\text { solution for Muzakki to } \\
\text { channel his zakat. } \\
\text { 3) The government has } \\
\text { not been fully involved } \\
\text { in mentoring and } \\
\text { coaching Mustahik } \\
\text { 4) The involvement of } \\
\text { other parties is still } \\
\text { lacking } \\
\text { 5) Other Amil Zakat } \\
\text { Institutions provide } \\
\text { more attractive } \\
\text { programs so that they } \\
\text { become a special } \\
\text { attraction for Muzakki } \\
\text { and Mustahik. } \\
\text { 6) The productive zakat } \\
\text { funds that go into } \\
\text { Mustahik' s hands will } \\
\text { not be able to change } \\
\text { Mustahik 's economic } \\
\text { conditions to the } \\
\text { maximum. }\end{array}$ & & \\
\hline
\end{tabular}

Source: data processed by researchers 2020 


\subsection{Formulate Mustahik Mentoring and Coaching Strategies at BAZNAS North Sumatra}

After the analysis is carried out through the IFAS and EFAS tables, the strategies that must be carried out to solve internal and external problems will be analyzed BAZNAS North Sumatra realizing the vision and mission of welfare Mustahik towards North Sumatra full of blessings and developing services and empowerment and empowerment programs to improve Mustahik 's welfare. Following is the formulation of Mustahik,s mentoring and coaching strategies BAZNAS North Sumatra namely: SO Strategy (Strength, Opportunity)

The strategy of Strength, Opportunity is as follows:

1. Enhancing the Partnership Program

2. Creating the BAZNAS Reword Program (PRB) by providing reword to innovative assistants and creative Mustahik in developing their business.

3. Creating a Development concept in accordance with the concept of Islamic sharia

4. Creating attractive and innovative services by publishing newsletters.

\subsection{Recommendation Policies in Assistance and Development of Mustahik at Baznas} North Sumatra

Table 6. Policy Directions for the Improvement of the North Sumatra BAZNAS

Assistance and Development Program

\begin{tabular}{|c|c|}
\hline $\begin{array}{l}\text { Period of } \\
\text { time }\end{array}$ & Policy Direction \\
\hline $\begin{array}{l}\text { Long-term } \\
\text { (1 year) }\end{array}$ & $\begin{array}{l}\text { 1. Increase mentoring and coaching programs from the internal side } \\
\text { BAZNAS North Sumatra in the field, } \\
\text { a. Increase HR BAZNAS North Sumatra } \\
\text { b. Maximizing the use of technology media for mentoring } \\
\text { and coaching Mustahik on line, } \\
\text { c. Creating a concept of mentoring and coaching in } \\
\text { accordance with the concept of Islamic sharia. } \\
\text { 2. Increase mentoring and coaching programs from the external side } \\
\text { BAZNAS North Sumatra in the field; } \\
\text { a. Cooperating with the government in mentoring and } \\
\text { fostering Mustahik, } \\
\text { b. Involving BUMD and BUMN, and private sector in } \\
\text { optimizing performance BAZNAS North Sumatra in } \\
\text { Mustahik's assistance and guidance, } \\
\text { c. Strengthening partnerships with state or private } \\
\text { universities, MSMEs, and other business entities, }\end{array}$ \\
\hline $\begin{array}{l}\text { Medium- } \\
\text { term } \\
(6 \text { months })\end{array}$ & $\begin{array}{l}\text { a. Establish cooperation with partners who have the same } \\
\text { vision and mission as BAZNAS North Sumatra } \\
\text { b. Increase capacity building, adjusted to developments } \\
\text { BAZNAS North Sumatra } \\
\text { c. Implement various methods so that muzaki are involved } \\
\text { in Mustahik's mentoring and guidance } \\
\text { d. Involving various stakeholders, experts, professional } \\
\text { assistants, or the community. }\end{array}$ \\
\hline $\begin{array}{l}\text { Short-term } \\
\text { (3 months) }\end{array}$ & $\begin{array}{l}\text { a. Creating attractive and innovative programs, } \\
\text { b. Designing digital communication programs that can } \\
\text { facilitate communication. }\end{array}$ \\
\hline
\end{tabular}




\begin{tabular}{|l|l|}
\hline c. & Conduct training and development for employees \\
& BAZNAS North Sumatra created the Baznas Reword \\
Program (PRB) by providing reword to innovative \\
assistants and creative Mustahik in developing their \\
business, \\
d. Maximizing the available funds for the development of \\
Mustahik's mentoring and guidance programs, \\
e. $\begin{array}{l}\text { the strength of Mustahik's mentoring and coaching } \\
\text { program. }\end{array}$
\end{tabular}

\section{Conclusion}

\subsection{Conclusion}

a. BAZNAS North Sumatra currently has not provided comprehensive assistance and guidance to productive zakat recipient Mustahik, this is due to the lack of existing human resources.

b. The results showed that Program Accompaniment North Sumatra BAZNAS has been proclaimed, but the implementation is still inadequate, mentoring and coaching. It has been implemented to recipients of productive revolving loans, although only briefly in the form of visits.

c. The strategy offered to North Sumatra BAZNAS is Strategy (SO), which emphasizes 1) Increasing the Partnership Program. 2) Creating a BAZNAS Reword Program (PRB) by providing reword to innovative assistants and creative Mustahik in developing their business. 3) Creating a development concept in accordance with the concept of Islamic sharia. Creating attractive and innovative services by publishing newsletters.

\subsection{Future Research Suggestions}

Due to limited time and ability, the researchers recommend several important points to be followed up by other researchers who want to continue this research

a. For the next researcher to further develop this mentoring model into further research studies so as to find a model of mentoring and coaching that is in accordance with the efforts developed by Mustahik who are productive zakat recipients, it is hoped that this will result in comprehensive assistance and guidance for Mustahik which ultimately leads to the birth of new muzaki muzaki in middle of society

b. For other researchers, this research still needs improvement. This is due to the limitations of researchers in terms of limited time, funds, and even capabilities. The researcher hopes that future studies related to Mustahik's mentoring and guidance in the management of productive zakat can study more comprehensively and specifically and be able to get more significant results.

\section{References}

https: // www. Indonesia. go.id/ religion. Data accessed on 23 July 2019. At 9.34. wib.

Megawati, Devi, Evaluation of the Mustahiq Empowerment Program "Etawa Goat At the City Baz Week, Pekbis Journal, 6.3 (2014),

Rahmat Hidayat and Ricky. Rahmat, "Swot Analysis as a Basis for Marketing Strategy Decisions in Credit Server Companies in Batam City (Case Study at Cv. Star Pratama)," Journal of Applied Business Administration Vol 2, No. 1, March 2018, 
2.1 (2018), 94-108 <https://jurnal.polibatam.ac.id/ index.php/JABA /article/ download /745/551>.

Mulyati Purwasasmita, "Strategy of Assistance for the Improvement of Community Beujar Independence," UPI Educational Administration Journal, 12.2 (2010).

Bambang Adi Suryono, UMKM Facilitator Assistance Patterns in Creating Rebana Center, Journal of Education for All, Vol 2 No. 1 Year 2018,

A. Mangunhardjana, Coaching: Meaning and Method, (Yogjakarta: Kanisius, 1991).

Mondy R Wayne Human Resource Management, (Jakarta: Erlangga, 2008)

Joyce. M. Hawkins, English-Indonesian, Indonesian-English Dual Dictionary, (OxfordErlangga. 1996)

Didin Hafidhuddin, Zakat in a Modern Economy, (Jakarta: Gema Insani Press Cet. II, 2002),

Law of the Republic of Indonesia Number 38 of 1999 Article 1 concerning Management of Zakat,

Hasbi ash-shiddieqy, Zakat Law, (Semarang: PT Pustaka Rizki Putra, 2002)

Ari Haryanto Chandra, The Impact of Productive Infaq Utilization on Increased Income at Mustahiq Ydsf (Al-Falah Social Fund Foundation) in Kediri JESTT Vol. 1 No. 10 October 2014,"1.10 (2014),

Moleong, LJ, Qualitative Research Methods Revised Edition, (Bandung: Pt. Remaja Rosdakarya, 2011),

Miles and Huberman, Qualitative Data Analysis, (Jakarta: UI-Press, 1992)

Henry Mintzberg, The Rise And Fall Of Strategic Planning, New York: Free Press, 1994.

Erhad. K. Valentin, Away Whitn SWOT Analysis: Use Defensive Offensive Evalation Instead", in Journal Of Applied Business Research Spring, 2005, Vol 2i, No. 2. 